\title{
Viability of Libidibia ferrea (Mart. ex Tul.) L.P. Queiroz var. ferrea) seeds by tetrazolium test ${ }^{1}$
}

\author{
Sara Monaliza Costa Carvalho ${ }^{2 *}$, Salvador Barros Torres², \\ Clarisse Pereira Benedito ${ }^{2}$, Narjara Walessa Nogueira², \\ Antonia Adailha Torres Souza², Maria Lilia de Souza Neta²
}

\begin{abstract}
Rapid tests have been essential to evaluate the physiological potential of seeds and the tetrazolium test is one of those which have been used by seed companies. The objective of the study was to establish the procedure for the tetrazolium test in Libidibia ferrea (Mart. Ex Tul.) L.P. Queiroz var. ferrea seeds. For this, three tetrazolium solution concentrations $(0.05$, 0.075 and $0.1 \%$ ) and three staining periods (1,3 and 6 hours) at temperatures of 35 to $40{ }^{\circ} \mathrm{C}$ were tested. The seeds were also evaluated by the germination test, whose result was compared with viability by the tetrazolium test. The experimental design was completely randomized in a factorial design $3 \times 3+1$ (three concentrations $\mathrm{x}$ three periods $+\mathrm{a}$ control = germination test) for each temperature. Viable seeds in the tetrazolium test were compared by Tukey's test $(p \leq 0.05)$, while the comparison between the viable seeds with germination test was carried out by Dunnett's test $(p \leq 0.05)$. It is recommended that the tetrazolium test for L. ferrea is carried out at a concentration of $0.05 \%$ for three-hour staining under $35{ }^{\circ} \mathrm{C}$ or $40{ }^{\circ} \mathrm{C}$.
\end{abstract}

Index terms: Fabaceae, forest seeds, rapid tests.

\section{Viabilidade de sementes de Libidibia ferrea (Mart. ex Tul.) L.P. Queiroz var. ferrea avaliada pelo teste de tetrazólio}

\begin{abstract}
RESUMO - Os testes rápidos têm sido imprescindíveis na avaliação do potencial fisiológico de sementes, sendo o de tetrazólio um dos que vêm sendo empregados pelas empresas produtoras de sementes. Assim, objetivou-se estabelecer o procedimento adequado para o teste de tetrazólio em sementes de Libidibia ferrea (Mart. ex Tul.) L.P. Queiroz var. ferrea. Para isso, testaram-se três concentrações da solução de tetrazólio $(0,05 ; 0,075$ e $0,1 \%)$ e três períodos de coloração $(1,3$ e 6 horas $)$ sob as temperaturas de 35 e $40{ }^{\circ} \mathrm{C}$. As sementes também foram avaliadas pelo teste de germinação visando a comparação com a viabilidade obtida pelo teste de tetrazólio. O delineamento experimental foi o inteiramente casualizado em esquema fatorial $3 \times 3+1$ (três concentrações $\times$ três períodos + uma testemunha = teste de germinação), para cada temperatura. As médias de sementes viáveis no teste de tetrazólio foram comparadas pelo teste de Tukey $(\mathrm{p} \leq 0,05)$, enquanto a comparação entre as médias de sementes viáveis com o teste de germinação foi realizada pelo teste de Dunnett $(\mathrm{p} \leq 0,05)$. Recomenda-se que o teste de tetrazólio para L. ferrea seja realizado na concentração de $0,05 \%$ por três horas de coloração, sob $35^{\circ} \mathrm{C}$ ou $40{ }^{\circ} \mathrm{C}$.
\end{abstract}

Termos para indexação: Fabaceae, sementes florestais, testes rápidos.

\section{Introduction}

Libidibia ferrea (Mart. ex Tul.) L.P. Queiroz var. ferrea, Fabaceae, commonly known as pau ferro, Brazilian ironwood, or leopard tree, is a Brazilian native species of multiple uses for its wood, landscape, medicinal and forage attributes, also prescribed for the recovery of degraded areas (Santana et al., 2011).

Seeds constitute the main reproductive route of $L$. ferrea.
Therefore they need attention regarding quality. However, determining seed viability of this species by a germination test takes long and over 20 days are necessary for its conclusion (Brasil, 2013). This long period makes it difficult to make decisions regarding the use of seeds for storage, sowing, marketing or disposal purposes.

In this sense, the tetrazolium test has been a promising alternative in determining viability and vigor of seeds of

${ }^{1}$ Submitted on $05 / 11 / 2016$. Accepted for publication on $02 / 03 / 2017$.

${ }^{2}$ Departamento de Ciências Vegetais, Universidade Federal Rural do Semi-Árido, Caixa Postal 137, 59625-900 - Mossoró, RN, Brasil.

*Corresponding author < saramonaliza@ufersa.edu.br $>$ 
several forest species due to its reliability and speed of results (Nogueira et al., 2014). This test is based on an alteration of the living tissues staining in the presence of tetrazolium salt solution, which is reduced by the activity of dehydrogenase enzymes involved in respiratory activity (Fogaça et al., 2011). During respiration, the release of hydrogen ions with which the 2,3,5-triphenyl-tetrazolium chloride (TTC) solution, which is colorless and soluble, reacts and forms triphenylformazan, which is stable, non-diffusible and reddish in color (Lazarotto et al., 2011).

Although the tetrazolium test is not so recent its use is still limited, which can be attributed to the need to develop procedures suitable for each species (Rezende et al., 2015). For this reason, research has been developed in an attempt to define adequate procedures for several forest species, according to Fogaça et al. (2011) with Copaifera langsdorffii Desf. and Schizolobium parahyba (Vell.) Blake.; Lazarotto et al. (2011) with silk floss tree (Ceiba speciosa A.St.-Hil.); Fava and Albuquerque (2013) with douradinha-do-campo (Palicourea rigida Kunth.); Nogueira et al. (2014) with pacara earpod tree (Enterolobium contortisiliquum (Vell.) Morong.); Kaiser et al. (2014) with pitanga (Brazilian cherry) (Eugenia uniflora L.); Gimenez et al. (2014) with graviola (Annona cherimola Mill.); Garlet et al. (2015) with gold medallion tree (Cassia leptophylla Vogel.); Cunha and Gomes (2015) with mulungu (Erythrina velutina Willd.) and Oliveira et al. (2016) with pereiro-vermelho (Simira gardneriana M.R. Barbosa \& Peixoto). In these studies, in addition to the procedures that preceded the test, staining times, tetrazolium solution concentrations and incubation temperatures were tested, factors that directly influence the uniformity of seed coloration (Bhering et al., 2005).

In this sense, the objective was to establish a proper procedure for conducting a tetrazolium test in seeds of $L$. ferrea.

\section{Material and Methods}

The experiment was carried out in the Laboratory of Seed Analysis of the Center of Agricultural Sciences of the Brazilian Federal Rural University of the Semi-Arid (UFERSA - Universidade Federal Rural do Semi-Árido), Mossoró, RN. The seeds were provided by the Reference Center for the Recovery of Degraded Areas (CRAD - Centro de Referência para Recuperação de Áreas Degradadas) at Brazilian Federal University of São Francisco Valley (UNIVASF - Universidade Federal do Vale do São Francisco), and the fruits were harvested in June 2012 on the farm Cacimba Nova, in the Brazilian city of Conceição, PB ( $07^{\circ} 33^{\prime} 44^{\prime}$ ' S, $38^{\circ} 30^{\prime}$ '32” W and $376 \mathrm{~m}$ of altitude). Seeds were packed in a plastic bag and stored in a cold room (at $10{ }^{\circ} \mathrm{C}$ and $50 \%$ relative humidity) for three years until the beginning of the experimental phase.

Firstly, the seeds water content was determined by the oven method at $105{ }^{\circ} \mathrm{C} \pm 3{ }^{\circ} \mathrm{C}$ for 24 hours (Brasil, 2009). The soaking curve was determined, with seeds manually scarified with sandpaper number 80 in the area opposite to the micropyle and non-scarified, in two subsamples of 50 seeds for each procedure. Seeds were arranged on three sheets of paper towel (Germitest $\AA$ ) moistened with distilled water in an amount of 2.5 times the mass of the dry paper, folded in rolls, packed in a plastic bag and placed in germination chambers of the Biochemical Oxygen Demand (B. O. D) type at $25^{\circ} \mathrm{C}$.

Before being soaked, seeds were weighed (initial weight) during the process at regular intervals. For this, seeds were removed, dried in paper towel and weighed in a precision scale $(0.001 \mathrm{~g})$ until $50 \%$ presented emission of the primary root for each subsample. Weighing intervals were every 60 minutes (from the beginning to five hours of soaking); every two hours (from 6 to 14 hours of soaking); and at intervals of three hours (from 14 to 52 hours of soaking), during which time the primary root grew. Seeds weight gain was calculated according to the formula proposed by Cromarty et al. (1985): $\mathrm{MG}=\left(\mathrm{F}_{\mathrm{w}}-\mathrm{I}_{\mathrm{w}} / \mathrm{I}_{\mathrm{w}}\right) \times 100$, where: $\mathrm{MG}=$ Moisture gain, $\mathrm{Iw}=$ Initial weight of the seeds before soaking and $\mathrm{FW}=$ Final weight (moisture gain at each soaking period).

For the tetrazolium test, seeds were initially scarified with sandpaper No. 80 and pre moistened in paper towel for 42 hours, based on the soaking curve results. Next, with the aid of a scalpel, the tegument was removed from the seeds, which were placed in $50 \mathrm{~mL}$ plastic cups and added to a solution of 2,3,5-triphenyl tetrazolium chloride in three concentrations $(0.05,0.075$ and $0.1 \%)$ for three staining periods $(1,3$, and 6 hours) under temperatures $35^{\circ} \mathrm{C}$ and $40{ }^{\circ} \mathrm{C}$, in a B.O.D. type greenhouse in the absence of light. For each combination, four subsamples of 25 seeds were used. After each staining period, the tetrazolium solution was drained and the seeds were washed in running water and placed in water. It was then placed in a refrigerator until the evaluation time.

During the evaluation, the two cotyledons were separated to also allow the analysis of the seed internal structure. Evaluation was done with the aid of table magnifying glasses and seeds were classified as viable or inviable according to the staining pattern indicated by França-Neto et al. (1998): light pink (healthy tissue); red (tissue in a deterioration process), and without staining (dead tissue). Seeds were evaluated considering not only the staining but the location, intensity and extent of staining. Viable seeds were those that presented bright light pink color, tissues with normal and firm appearance, an embryonic axis with an intense red color, 

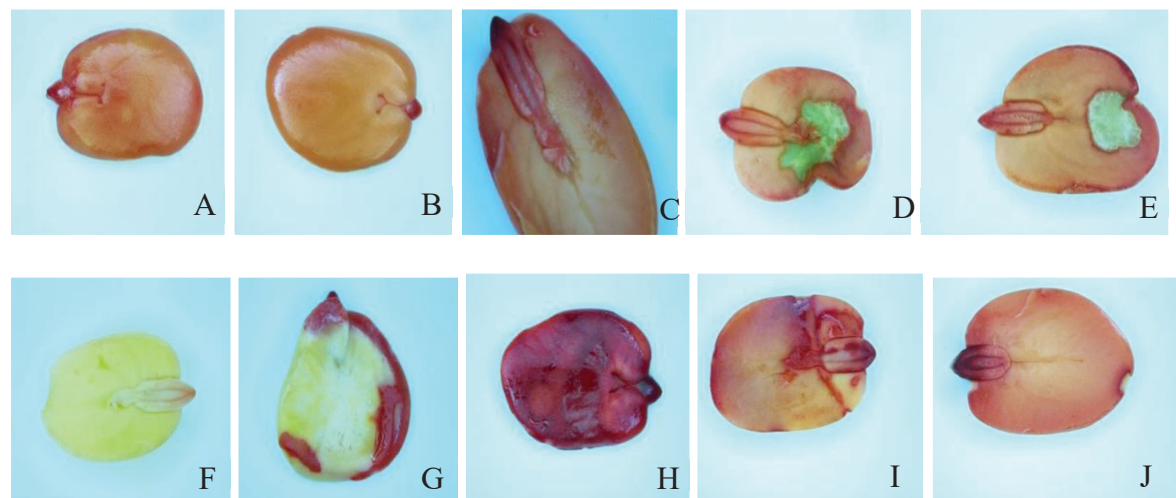

Figure 1. Seeds of Libidibia ferrea (Mart. ex Tul.) L.P. Queiroz var. ferrea considered viable by the tetrazolium test: Seeds with bright light pink color, normal and firm looking tissues (A and B); Embryonic axis with an intense red color, not reaching the central cylinder $(\mathrm{C})$; Less than $50 \%$ of discolored cotyledons, cotyledons with necrotic regions but not affecting the area of attachment to the embryonic axis (D and E); and unviable: completely discolored seeds (F); With more than $50 \%$ of discolored cotyledons $(\mathrm{G})$; With an intense red color in all parts $(\mathrm{H})$; Embryonic axis with an intense red color reaching the central cylinder (I and J).

although without reaching the central cylinder, less than 50\% of discolored cotyledons, and cotyledons with necrotic regions but without affecting the area of attachment to the embryonic axis (Figure 1). The inviable ones were those shown with more than $50 \%$ of discolored cotyledons, with an intense red coloration or necrotic, an embryonic axis with discolored areas, in an intense red color and/or necrosed, reaching the central cylinder (Figure 1) (Nogueira et al., 2014). Results were expressed as percentages of viable seeds.

In order to obtain a comparison standard of the results, a germination test was concomitantly carried out using four subsamples of 25 seeds arranged in transparent plastic boxes (Gerbox $\left.{ }^{\circledR}\right)(11 \times 11$ x $3.5 \mathrm{~cm})$ containing sand washed, sterilized and moistened with $60 \%$ of its field capacity, at $30{ }^{\circ} \mathrm{C}$ (Lima et al., 2006). Evaluation was performed twenty days after sowing and the data were expressed as percentage of normal seedlings (Brasil, 2013).

The experimental design was a completely randomized $3 \times 3+1$ factorial arrangement (three concentrations of the solution times three staining periods plus one control $=$ germination test) under temperatures of $35^{\circ} \mathrm{C}$ and $40{ }^{\circ} \mathrm{C}$. The data, when submitted to variance normality and homogeneity tests presented normal distribution and it was not necessary to transform them. Means of viable seeds obtained by the tetrazolium test were compared by the Tukey's test $(p \leq 0.05)$. Comparison between the means of viable seeds with the germination test (control) was performed by Dunnett's test ( $\mathrm{p} \leq 0.05$ ), following recommendations by Banzatto and Kronka (2006). Statistical analyses were carried out by the ASSISTAT 7.7 beta software (Silva and Azevedo, 2002).

\section{Results and Discussion}

The initial moisture content level of L. ferrea was $10 \%$. Regarding water absorption behavior, those that were subjected to mechanical scarification gradually increased their degree of humidity and followed the three-phase pattern proposed by Bewley and Black (1994). On the other hand, non-scarified seeds absorbed an insignificant amount of water, remaining practically with the same initial moisture content, thus not complying to the three-phase germination pattern. As $L$. ferrea seeds present a tegumentary dormancy, only the scarified ones were able to emit a primary root, which was already expected, since the non-scarified ones remained with water content practically equal to the initial one (Figure 2).

Determining the water absorption curve is important to obtain information about seeds behavior in relation to water gain, a factor that can contribute many times to better penetration of the tetrazolium salt, besides causing seeds softening to accomplish cuts (Bhering et al., 1996).

In the three-phase germination pattern, Phase $\mathrm{I}$ is characterized by water inflow due to the difference in matrix potential between seeds and the external environment. The matrix potential is the seed ability to absorb water through cell walls and macromolecules (polysaccharides and proteins) (Bewley and Black, 1994). This physical process depends only on the water binding to the seed matrix, occurring in any material, dead or living, which contains sites of binding or affinity for water (Borghetti, 2004).

In this way, viability does not interfere in this process, since it is a purely physical phenomenon, so that even dead seeds 
are able to absorb water in this first phase. In the case of the $L$. ferrea seeds, this phase was completed after 32 hours of soaking, characterizing as the longest phase of the process. Depending on the species, the duration of Phase I is quite variable. In seeds of Adenanthera pavonina L., Mantoan et al. (2012) have reported that this phase lasted three hours. In Copernicia hospita Martius seeds, Oliveira and Bosco (2013) verified that it was of two hours. As for Jatropha curcas L., Smiderle et al. (2013) have verified a duration of 32 hours. In Simira gardneriana seeds (Oliveira et al., 2016) this phase was completed after 33 hours of soaking. At the end of Phase I, L. ferrea seeds showed moisture content of $40 \%$, which is expected for cotyledonary seeds, as emphasized by Guimarães et al. (2008).

Phase II had a much shorter duration compared to Phase I. However, it is possible to notice that water absorption occurred more slowly. This is because there is a tendency to stabilize and balance water absorption by the seed in relation to the environment since cells inside the seeds have already reached an expansion limit (Castro et al., 2004).

According to Carvalho and Nakagawa (2012), from water content between 35 to $40 \%$ for endosperm ones and from 50 to $60 \%$ for cotyledonary ones, Phase III begins, which was confirmed for L. ferrea seeds, which started such phase with moisture level a little higher than $50 \%$. This phase starts from the moment the radicle breaks the integument and is released to the external environment, turning to the denomination of primary root. This is due to successive meristematic tissue mitoses (cell divisions), which cause the growth of the embryonic axis. In this phase, the presence of water is essential since the seed is in an intense process of mitotic division and this event is extremely dependent on water. Unviable and dormant seeds can not reach this phase (Bewley and Black, 1994).

Viability results of $L$. ferrea seeds regarding the combinations of periods and concentrations under temperature $35^{\circ} \mathrm{C}$ indicate that the period of one hour has resulted in low viability means, regardless of the solution concentration (Table 1). In the period of six hours, except for the concentration of $0.075 \%$, viability means lower than the ones obtained in the germination test have also been observed. In the period of three hours for all concentrations results similar to the one obtained in the germination test have been observed.

Such results demonstrate that the time of one hour was insufficient for staining the seeds, thus not allowing an appropriate staining. In contrast, the time of six hours (except for the concentration of $0.075 \%$ ) was excessive for staining the seeds, whose tissues colored very intensely, making it difficult to interpret the results. Nogueira et al. (2014), working with pacara earpod tree (Enterolobium contortisiliquum) seeds, a species also belonging to the Fabaceae family, have observed results similar to those found in this research.

Under the temperature of $40^{\circ} \mathrm{C}$, similar to what occurred at $35^{\circ} \mathrm{C}$, the period of one hour has proved to be insufficient to estimate the viability of $L$. ferrea seeds (Table 2 ). However, an increase of viability regarding what was obtained at temperature $35^{\circ} \mathrm{C}$ was noticed for this period. In the period of six hours, except for the concentration of $0.05 \%$, results were different from the ones observed by the germination test. Also, for this temperature the three-hour period was the one that gave satisfactory results, having occurred in all concentrations and in means of viability that did not differ from the control (germination test).

Analyzing the viability results of $L$. ferrea seeds in relation to the concentrations, it is possible to notice that under temperatures

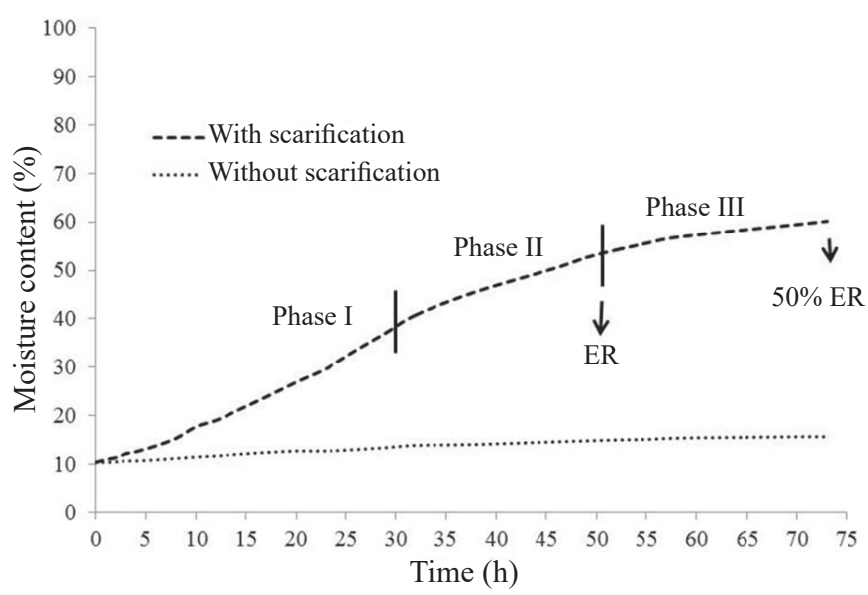

Figure 2. Soaking of seeds of Libidibia ferrea (Mart. ex Tul.) L.P. Queiroz var. ferrea with and without scarification, at $25{ }^{\circ} \mathrm{C}$. ER $=$ Primary root emission; $50 \% \mathrm{ER}=50 \%$ of seeds with primary root emission.

Table 1. Viability means of seeds of Libidibia ferrea (Mart. ex Tul.) L.P. Queiroz var. ferrea from the tetrazolium test conducted at different staining concentrations and periods under temperature of $35^{\circ} \mathrm{C}$.

\begin{tabular}{cccc}
\hline \multirow{2}{*}{ Period (h) } & \multicolumn{3}{c}{ Concentrations (\%) } \\
\cline { 2 - 4 } & $0.050^{*}$ & 0.075 & 0.100 \\
\hline 1 & $23 \mathrm{cBy}$ & $38 \mathrm{bAy}$ & $31 \mathrm{bABy}$ \\
3 & $71 \mathrm{aAx}$ & $74 \mathrm{aAx}$ & $67 \mathrm{aAx}$ \\
6 & $34 \mathrm{bBy}$ & $78 \mathrm{aAx}$ & $8 \mathrm{cCy}$ \\
\hline
\end{tabular}

Germination (\%) $76 \mathrm{x}$

*Means followed by the same uppercase letter (A, B, C) in the row and lowercase $(\mathrm{a}, \mathrm{b}, \mathrm{c})$ in the column do not differ significantly by the Tukey's test at $5 \%$ probability. Means followed by the same letter $(x, y)$ between germination (control - germination test) and viability obtained in the tetrazolium test do not differ significantly by the Dunnett's test at $5 \%$ probability. 
Table 2. Viability means of seeds of Libidibia ferrea (Mart. ex Tul.) L.P. Queiroz var. ferrea from the tetrazolium test conducted at different staining concentrations and periods under temperature of $40^{\circ} \mathrm{C}$.

\begin{tabular}{cccc}
\hline \multirow{2}{*}{ Period (h) } & \multicolumn{3}{c}{ Concentrations (\%) } \\
\cline { 2 - 4 } & $0.050^{*}$ & 0.075 & 0.100 \\
\hline 1 & $41 \mathrm{cAy}$ & $47 \mathrm{bAy}$ & $42 \mathrm{bAy}$ \\
3 & $84 \mathrm{aAx}$ & $81 \mathrm{aAx}$ & $76 \mathrm{aAx}$ \\
6 & $67 \mathrm{bAx}$ & $31 \mathrm{cBy}$ & $18 \mathrm{cCy}$ \\
\hline Germination $(\%)$ & \multicolumn{4}{c}{$76 \mathrm{x}$} \\
\hline
\end{tabular}

* Means followed by the same uppercase letter $(\mathrm{A}, \mathrm{B}, \mathrm{C})$ in the row and lowercase $(a, b, c)$ in the column do not differ significantly by the Tukey's test at $5 \%$ probability. Means followed by the same letter $(\mathrm{x}, \mathrm{y})$ between germination (control - germination test) and viability obtained in the tetrazolium test do not differ significantly by the Dunnett's test at $5 \%$ probability.

$35^{\circ} \mathrm{C}$ and $40^{\circ} \mathrm{C}$ all concentrations provided results similar to the ones in the germination test (Tables 1 and 2).

For both temperatures tested, the combinations of periods and concentrations that differed from the control can be justified by not developing an adequate staining in the various combinations, which led to the classification of viable seeds in the category of nonviable, thus underestimating the seeds physiological potential.

Although the viability results for $L$. ferrea seeds have shown the possibility of carrying out the tetrazolium test in different combinations (period versus concentration) both at 35 ${ }^{\circ} \mathrm{C}$ as at $40{ }^{\circ} \mathrm{C}$, the choice of the most appropriate procedure should take into account the lower amount of time spent for staining as well as the lower cost with the reagent. In addition, lower concentrations are better indicated because they allow better visualization of discoloration disorders and identification of different types of injuries (Krzyzanowski et al., 1999). Therefore, the tetrazolium test at the concentration of $0.05 \%$ for three hours under temperatures of $35{ }^{\circ} \mathrm{C}$ or $40{ }^{\circ} \mathrm{C}$ can be recommended for evaluating the viability of $L$. ferrea seeds.

Although there are no indications of low concentrations for any of the forest species described in the recommendations contained in the Brazilian government Rules for Seed Testing [R.A.S. (Regras para Análise de Sementes)] (Brasil, 2009) for conducting the tetrazolium test in seeds, more recent research has demonstrated efficiency in the use of lower concentrations, as observed in this work. Results evidencing efficiency of the use of the concentration of $0.05 \%$ can be found in works by Lamarca et al. (2009) with Brazilwood or Pernambuco tree (Caesalpinia echinata Lam.); Guedes et al. (2010) with amburana (Amburana cearensis A. C. Smith.); Lazarotto et al. (2011) with silk floss tree (Ceiba speciosa) and Abbade and Takaki (2014) with white ipê (Tabebuia roseoalba (Ridl.) Sandwith).

\section{Conclusions}

To carry out the tetrazolium test in $L$. ferrea seeds it is necessary to pre-scarify the seeds with sandpaper No. 80 , followed by pre-wetting between paper towels for 42 hours at $25^{\circ} \mathrm{C}$ and removal of the tegument.

Viability of $L$. ferrea seeds may be assessed using the concentration of $0.05 \%$ of tetrazolium salt at $35{ }^{\circ} \mathrm{C}$ or $40{ }^{\circ} \mathrm{C}$ for three hours soaking.

\section{References}

ABBADE, L.C.; TAKAKI, M. Teste de tetrazólio para avaliação da qualidade de sementes de Tabebuia roseoalba (Ridl.) Sandwith Bignoniaceae, submetidas ao armazenamento. Revista Árvore, v.38, n.2, p.233-240, 2014. http://www.scielo.br/pdf/rarv/v38n2/03.pdf

BANZATTO, D.A.; KRONKA, S.N. Experimentação agrícola. $4^{\mathrm{a} e d .}$ Jaboticabal: FUNEP, 2006. 237 p.

BEWLEY, J.D.; BLACK, M. Seeds: physiology of development and germination. $2^{a}$ ed. New York: Plenum Press, 1994. 445 p.

BHERING, M.C.; SILVA, R.F.; ALVARENGA, E.M.; DIAS, D.C.F.S.; PENA, M.F. Avaliação da viabilidade e do vigor das sementes de feijão-de-vagem (Phaseolus vulgaris L.) pelo teste de tetrazólio. Viçosa: UFV, 1996. 27p.

BHERING, M.C.; DIAS, D.C.F.S.; BARROS, D.I. Adequação da metodologia do teste de tetrazólio para avaliação da qualidade fisiológica de sementes de melancia. Revista Brasileira Sementes, v. 27 , n. 1, p. 176-182, 2005. http://www.scielo.br/pdf/\%0D/rbs/ v27n1/25196.pdf

BRASIL. Ministério da Agricultura, Pecuária e Abastecimento. Regras para análise de sementes. Ministério da Agricultura, Pecuária e Abastecimento. Secretaria de Defesa Agropecuária. Brasília: MAPA/ACS, 2009. 395p. http://www.agricultura.gov.br/arq_editor/ file/2946_regras_analise_sementes.pdf

BRASIL. Ministério da Agricultura, Pecuária e Abastecimento. Instruções para análise de sementes. Brasília, DF: MAPA, 2013. 98p. http://www.agricultura.gov.br/arq_editor/file/Laboratorio/Sementes/ FLORESTAL documento pdf.pdf

BORGHETTI, F. Dormência embrionária. IN: FERREIRA, A.G.; BORGHETTI, F. (Org.). Germinação: do básico ao aplicado. Porto Alegre: Artmed, 2004. p. 109-123.

CARVALHO, N.M.; NAKAGAWA J. Sementes: ciência, tecnologia e produção. $5^{\text {a }}$ ed. Jaboticabal: FUNEP, 2012. 590 p.

CASTRO, R.D.; BRADFORD, K.J.; HILHORST, H.W.M. Embebição e reativação do metabolismo. IN: FERREIRA, A.G.; BORGHETTI, F. (Eds.) Germinação: do básico ao aplicado. Porto Alegre: Artmed, 2004. p.149-162. 
CROMARTY, A.S.; ELLIS, R.H.; ROBERTS, E.H. Design of seed storage facilities for genetic conservation. Rome: Internacional Board of Plant Genetic Resources, 1985. 100p. https://www. bioversityinternational.org/fileadmin/_migrated/uploads/ tx_news/The_design_of_seed_storage_facilities_for_genetic conservation_281.pdf

CUNHA, M.C.L.; GOMES, I.H.R.A. Viabilidade de sementes de Erythrina velutina Willd. pelo teste de tetrazólio. Nativa, v.3, n.3, p.196-200, 2015. http://periodicoscientificos.ufmt.br/index.php/ nativa/article/view/2304

FAVA, C.L.F.; ALBUQUERQUE, M.C. F. Viabilidade e emergência de plântulas de Palicourea rigida Kunth em função de diferentes métodos para superação de dormência. Enciclopédia Biosfera, v.9, n.17, p.2620-2629, 2013. http://www.conhecer.org.br/ enciclop/2013b/CIENCIAS\%20AGRARIAS/VIABILIDADE\%20 E\%20EMERGENCIA.pdf

FOGAÇA, C.A.; KROHN, N.G.; SOUZA, M.A.; PAULA, R.C. Teste de tetrazólio em sementes de Copaifera langsdorffii e Schizolobium parahyba. Floresta, v.41, n.4, p.895-904, 2011. http://ojs.c3sl.ufpr. br/ojs/index.php/floresta/article/view/25352

FRANÇA-NETO, J.B.; KRZYZANOWSKI, F.C.; COSTA, N.P. $O$ teste de tetrazólio em sementes de soja. Londrina: EMBRAPA/ CNPSO, 1998. 72p. http://www.agrolink.com.br/downloads/ TRETRAZ\%C3\%93LIO.pdf

GARLET, J.; SOUZA, G.F.; DELAZERI, P. Teste de tetrazólio em sementes de Cassia leptophylla. Enciclopédia Biosfera, v.11 n.21, p.1800-1808, 2015. http://www.conhecer.org.br/enciclop/2015b/ agrarias/teste $\% 20 \mathrm{de} \% 20 \% 20$ tetrazolio.pdf

GIMENEZ, J.I.; FERREIRA, G.; CAVARIANI, C. Tetrazolium test for assessment of seed viability of atemoya (Annona cherimola Mill. x A. squamosa L). Journal of Seed Science, v.36, n.3, p. 357-361, 2014. http://www.scielo.br/pdf/jss/v36n3/12.pdf

GUEDES, R.S.; ALVES, E.U.; GONÇALVES, E.P.; VIANA, J.S.; SILVA, K.B.; GOMES, M.S.S. Metodologia para teste de tetrazólio em sementes de Amburana cearensis (Allemao) A.C. Smith. Revista Brasileira de Plantas Medicinais, v.12, n.1, p.120-126, 2010. http://www. scielo.br/scielo.php?script=sci_arttext\&pid=S1516-05722010000100017

GUIMARÃES, M.A.; DIAS, D.C.F.S.; LOUREIRO, M.E. Hidratação de sementes. Revista Trópica - Ciências Agrárias e Biológicas, v.2, n.1, p.31-39, 2008. https://www.researchgate.net/ profile/Marcelo_Guimaraes/publication/246044401_Hidratacao_ de_sementes/links/0046351d8dd48d5620000000.pdf

KAISER, D.K.; FREITAS, L.C.N.; BIRON, R.P.; SIMONATO, S.C.; BORTOLINI, M.F. Adjustment of the methodology of the tetrazolium test for estimating viability of Eugenia uniflora L. seeds during storage. Journal of Seed Science, v.36, n.3, p.344-351, 2014. http://www.scielo.br/scielo.php?script=sci_ arttext\&pid=S2317-15372014000300010

KRZYZANOWSKI, F.C.; VIEIRA, R.D.; FRANCA-NETO, J.B. (Ed.). Vigor de sementes: conceitos e testes. Londrina: ABRATES, 1999. $218 \mathrm{p}$
LAMARCA, E.V.; LEDUC, S.N.M.; BARBEDO, C.J. Viabilidade e vigor de sementes de Caesalpinia echinata Lam. (pau-brasil Leguminosae) pelo teste de tetrazólio. Revista Brasileira de Botânica, v. 32, n.4, p.793-803, 2009. http://www.scielo.br/pdf/rbb/v32n4/ a17v32n4.pdf

LAZAROTTO, M.; PIVETA, G.; MUNIZ, M.F.B.; REINIGER, L.R.S. Adequação do teste de tetrazólio para avaliação da qualidade de sementes de Ceiba speciosa. Semina: Ciências Agrárias, v.32, n.4, p.1243-1250, 2011. http://www.uel.br/revistas/uel/index.php/ semagrarias/article/view/4771

LIMA, J.D.; ALMEIDA, C.C.; DANTAS, V.A.V.; SILVA, B.M.S.; MORAES, W.S. Efeito da temperatura e do substrato na germinação de sementes de Caesalpinia ferrea Mart. ex Tul. (Leguminosae, Caesalpinoideae). Revista Arvore, v.30, n.4, p.513-518, 2006. http://www. scielo.br/scielo.php?script=sci_arttext\&pid=S0100-67622006000400003

MANTOAN, P.; LEAL, T.S.; PESSA, H.I.; MARTELINE, M.A.; MORAES, C.P. Escarificação mecânica e química na superação de dormência de Adenanthera pavonina L. (Fabaceae: Mimosoideae). Scientia Plena, v.8, n.5, p.1-8, 2012. http://www.scientiaplena.org. $\mathrm{br} / \mathrm{sp} /$ article/view/100

NOGUEIRA, N.W.; TORRES, S.B.; FREITAS, R.M.O. Teste de tetrazólio em sementes de timbaúba. Semina: Ciências Agrárias, v.35, n.6, p.2967-2976, 2014. http://www.uel.br/revistas/uel/index. $\mathrm{php} /$ semagrarias/article/view/14704/pdf_521

OLIVEIRA, A.B.; BOSCO, M.R.O. Biometria, determinação da curva de absorção de água em sementes e emergência inicial de plântulas de Copernicia hospita Martius. Revista Brasileira de Agroecologia, v.8, n.1, p.66-74, 2013. http://www.aba-agroecologia. org.br/revistas/index.php/rbagroecologia/article/view/12704

OLIVEIRA, F.N.; TORRES, S.B.; NOGUEIRA, N.W.; FREITAS, R.M.O. Viability of Simira gardneriana M.R. Barbosa \& Peixoto seeds by the tetrazolium test. Journal of Seed Science, v.38, n.1, p.7-13, 2016. http://www.scielo.br/scielo.php?script=sci arttext\&pid=S2317-15372016000100007

REZENDE, R.G.; JESUS, L.L.; NERY, M.C.; ROCHA, A.S.; CRUZ, S.M.; ANDRADE, P.C.R. Teste de tetrazólio em sementes de crambe. Semina: Ciências Agrárias, v. 36, n.4, p.2539-2544, 2015. http://www.uel.br/revistas/uel/index.php/semagrarias/article/ view/13453

SANTANA, J.A.S.; FERREIRA, L.S.; COELHO, R.R.P.; VIEIRA, F.A.; PACHECO, M.V. Tecnologias de baixo custo para superação de dormência em sementes de Caesalpinia ferrea var. ferrea Mart. ex. Tul. (pau-ferro). Revista Verde de Agroecologia e Desenvolvimento Sustentável, v.6, n.1, p. 225-229, 2011. http://www.gvaa.com.br/ revista/index.php/RVADS/article/view/524

SILVA, F.A.S.; AZEVEDO, C.A.V. Versão do programa computacional Assistat para o sistema operacional Windows. Revista Brasileira de Produtos Agroindustriais, v.4, n.1, p.71-78, 2002. http://www.deag.ufcg.edu.br/rbpa/rev41/Art410.pdf

SMIDERLE, O.J.; LIMA, J.M.E.; SCHUERTZ, P.P.P. Curva de absorção de água em sementes de Jatropha curcas L. com dois tamanhos.RevistaAgro@mbiente On-line,v.7,n.2,p. 203-208,2013. http://revista.ufrr.br/index.php/agroambiente/article/view/1056 